\title{
"UM TORVELINHO DE INTENSIDADES": O TEXTO-QUERUBIM E DAÏMON DA ESCRITA
}

\author{
Maria de Lourdes Soares \\ (Universidade Federal do Rio de Janeiro)
}

\section{RESUMO}

A "presença angélica": um "torvelinho de intensidades", um canto "de louvor, de temor e de beleza". De figurante a figura: "um anjo a caminho". A Anunciação do "Anjo da Palavra". Luz/Lúcifer e a postura rebelde. Os daïmons sonoros e a "sensualética". O pandemônio de estéticas e suas "tentações". O demônio e o demoníaco. Sena/Anés e as "novas andanças do fulgor". O espaço edênico e "o jardim que o pensamento permite". D/eus, "Esse", "Presença Amante".

PALAVRAS-CHAVE: anjo; demônio; Maria Gabriela Llansol.

\section{ABSTRACT}

The "angelical presence": "a whirlwind of intensities", a song "of praise, awe and beauty". From figurant to an in informed figure: "an angel to come". The Annunciation of the "Angel of the Word". Light/Lucifer and the rebellious attitude. The reverberant daïmons and the "sensualethics". The aesthetic pandemonium and its "temptations". The devil and the demonic. Sena / Anés and the "new wanderings of the blaze. "The Edenic space" and "the garden enabled by contemplation". God, "Thy", "Loving Presence".

KEYWORDS: angel; devil; Maria Gabriela Llansol. 
Há um torvelinho de intensidades a chamar-nos: são os anjos de Rilke, ou as legiões de querubins incandescentes, de Walter Benjamin.

Maria Gabriela Llansol (1996, p. 48)

1.

Falar de anjos é uma das dobras ou insistências do texto de Maria Gabriela Llansol, assim como da poesia de Rilke, cujos poemas em francês a autora traduziu. No entanto, pouco ou quase nada a autora escreve sobre o demônio ou o demoníaco, no sentido consagrado no imaginário cultural, como figuração do mal e do maligno. Seu texto não segue a lógica das oposições binárias - Deus/Diabo, Bem/Mal, Paraíso/Inferno. "O Bem e o Mal escondiam a verdadeira divisão entre os humanos, quanto à Vida. Dividem-nos a Tristeza e a Alegria" (LLANSOL, 1987, p. 94). Desfaz hierarquias e polaridades, propondo nuances, contaminações, travessia de fronteiras rigidamente demarcadas: "Os círculos do obscuro não são totalmente infernais, nem os ângulos do paraíso totalmente luminosos, num e noutro lugar há impostura”; “- Também há tristeza no paraíso [...] - Também há alegria sobre a terra - diz-me Bach (LLANSOL, 1990, p. 9, 11). Fende o absoluto: "Decido, nessa altura natalícia, tirar o de de deus, e chamar eus ao que for a diferença que o prive de ser a sua vontade" (LLANSOL, 1985, p. 16-7). Põe em movimento a intensidade do mútuo, propondo a "emigração para um LOCUS/LOGUS, paisagem onde não há poder sobre os corpos, como, longinquamente, nos deve lembrar a experiência de Deus,/ fora de todo o contexto religioso, ou até sagrado" (LLANSOL, 1994, p. 121).

Os anjos estão presentes ao longo da obra llansoliana ${ }^{1}$, desde a serena espera de Maggie Only (personagem do conto homônimo do primeiro livro da autora, Os pregos na erva, 1962) pela vinda de Ângelo (latim angelus, do grego ággelos: anjo, mensageiro, enviado), como quem segura "uma maçã ainda não vermelha", convicção reafirmada contra a opinião de Petrus (latim: pedra, rocha): “- E se não vier?/ - Mas ele vem./ - E se não vier? - Mas ele vem” (LLANSOL, 1987a, p. 124), até Angelikos (figura do último livro publicado em vida, Os cantores de leitura, 2007), "Angelo / Azulado, do árabe lilak", o cantor de leitura "de quem apenas ouvimos os passos? O verbo?", que ofereceu à mulher "um angelim, árvore de madeira valiosa que tem por imaginário a eternidade" (LLANSOL, 2007, p. 79, 18, 168).

Os anjos de Llansol não correspondem às imagens angelicais do céu cristão. Aparecem numa surpreendente profusão e variedade de formas, inclusive na de animais-anjos. "Há cães que são anjos", como os cães Jade, Trova e Clamor, "misteriosos como os seus nomes", "serenos guias" do Há jubiloso: "No há que escolhi/, a minha espinha dorsal é o júbilo. Escrever/ está dentro do redil do paraíso, que é também uma sebe onde eu entro 
através do ar" (LLANSOL, 1996, p. 134-35, 72). Jade, nascido como uma "incidência animal alada", é o seu "Anjo Sublime da Guarda" e os gatos, seus "Anjos Independentes da Guarda". Mas há o anjo exterminador que nos torna mais brutos todos os dias, é o que expõem, de peito aberto, nos talhos (LLANSOL, 1991, p. 1, 19). Há também o “Anjo da História”, que permitiu o suicídio de Walter Benjamin (LLANSOL, 2007, p. 156).

\section{2.}

Quem escreve de algum modo espera a visita do anjo à sua mesa - acontecimento ao mesmo tempo aguardado e imprevisível. Nem sempre a escrita cede ao texto. Nem sempre há a "grande graça de textualidade", abrindo "acesso ao novo, ao vivo, ao fulgor". Atenta às "tonalidades particulares de cada encontro" (LLANSOL, 1994, p. 122, 135, 120), Gabriela procura captar de diferentes modos a força do anjo. Guarda a sua pujança, desligando-o do contexto religioso.

Em Um beijo dado mais tarde, Témia lia deitada "a súplica que a avó [a] fazia repetir" (provavelmente a oração ao Anjo da Guarda): "a criança que adormece a suplicar é o lugar da aprendizagem”. A narradora acolhe e re-dispõe a herança material e imaterial da casa familiar - preces e objetos, como o "Anjo de porcelana" e a estátua em madeira polícroma em que Sant'Ana ensina Maria a ler ('Ana ensinando a ler a Myriam'), transfigurando-os em "bens luminosos" (LLANSOL, 1990, p. 17-8, 9).

Num curioso registro de um de seus cadernos da Bélgica, Gabriela medita sobre a necessidade de "um guia" para acalmar o espírito (na época a autora experimentava a desilusão com o trabalho na cooperativa da Escola/ Quinta de Jacob e, paralelamente, escrevia Na casa de Julho e Agosto):

Gabriel, o arcanjo, será o teu dia, e guia. Várias vezes já nadaste entre duas margens e voltaste à primeira margem. Medita para ancorares o teu espírito. Gabriel, o arcanjo, te fornecerá / inspirará os temas de meditação [...].

Precisas de proferir todos os dias um ramo de palavras imutáveis que vou ajudar-te a escolher.

(Isto não é fantasia, é imaginação criadora) (LLANSOL, 2010, p. 195)

Dando curso à imaginação criadora, Gabriel e o tema de meditação, metamorfoseados, são incorporados ao trabalho gestatório do livro: "Mas meu guia/ Luís M./ Tejo-rio aconselha-me/ indica-me que domine o medo. Não vão os homens pensar que, quando me afasto deles, é porque os desprezo. Quando os temo” (LLANSOL, 2010, p. 196).

Na hierarquia dos anjos, são nove os Coros ou Ordens angélicas: Serafins, Querubins, Tronos, Dominações, Potestades, Virtudes, Principados, Arcanjos e Anjos. No texto de Llansol não há hierarquização de seres, mas reciprocidade, amor do mútuo, como o que une Ana e Myriam em 
sua estátua. Algumas das funções dos anjos, no entanto, são conservadas, como a de guia e proteção.

Gabriel, arcanjo homônimo de Gabriela, é o Anjo da Anunciação a Maria, segundo a tradição cristã. A autora reescreve a cena da Anunciação. Em Um beijo dado mais tarde, o "Anjo de porcelana", transfigurado em "Anjo da palavra", guia a narradora para "a clareira ou o pátio da floresta", e protege a relação de reciprocidade que se estabelece entre Ana e Myriam:

O conjunto de Sant'Ana e da aprendiza de leitura,

é a imagem do seu [de Témia] nascimento, a meu lado.

Força protectora do Anjo sobre a presença desta relação recíproca entre a mulher e a criança, uma e outra,

humildes servas no seu universo (LLANSOL, 1990, 17, 28)

Filha do amor de ler, nasce, portanto, uma segunda discípula, "o tu, 'a segunda pessoa de Myriam”', metamorfoseada em Têmia, e que também pode ser a desejada figura do legente, debruçado sobre o livro aberto no colo de Ana, ou ainda "o jovem rapaz feminino, ela", "Gabriel[a] Anunciando" (LLANSOL, 1990, p. 58, 62).

A cena da Anunciação retorna, em outra tonalidade, associada ao encontro na "sala do lume" entre o Mais Jovem (Vergílio Ferreira na ordem figural) e "a jovem mulher do seu amor":

Ela reconhece, apenas, que ali perante ela, está uma força que vem de muito longe e, mesmo se o seu poder de impacto é incalculável, nenhum mal lhe fará,

veio do imensamente longe dizer-lhe quanto a ama. Como o Anjo fizera com a Virgem (LLANSOL, 1996, p. 181-82)

Na verdade, Llansol "não descontr[ói] o anjo quando o escrev[e] - o movimento é outro" (LLANSOL, 1996, p. 30). Para acolher a força do anjo, precisa desconstruir imagens cristalizadas. "Muitos anjos não são as crianças que se imagina (que nós imaginamos) vitrais de inocência”, concepção que remete a uma consagrada representação da infância. "São idades esclarecidas em velhos - são velhos de artérias rejuvenescidas, com uma especialíssima estrutura de experiência do tempo. Angelikos talvez pertença ao termo dessa longa série espiritual". A Tual (um dos nomes figurais de Augusto Joaquim, marido de Gabriela), "um velho transparente", "poderia aplicar-se" a observação acima "sobre a renovação das estruturas", “já que os anjos [...] não são vitrais de inocência, mas um cruzamento melodioso de cores" (LLANSOL, 2007, p. 169).

A autora busca estabelecer com o anjo uma relação diversa da sugerida pela imagem trivial da sua infância, conforme a iconografia cristã costuma representar o Anjo da Guarda - um jovem de delicada beleza e grandes asas brancas que ajuda uma criança (ou duas, na representação mais conhecida) a atravessar um rio. Interessa-lhe encontrar saídas da escrita representativa que lhe permitam transitar do figurante à figura: 
uma criança - um caminho - um anjo - e a acção suspensa de um acontecimento iminente o anjo está a

proteger a criança de cair no abismo;

mas o que é o anjo e a criança passível de precipitar-se?; estão a estabelecer um contacto, sombreado pela decisão do anjo; são dois figurantes imbuídos um no outro e assim, em frases sucessivas, fui falando com o anjo, que me apontava a dissonância dos tempos e das fases (LLANSOL, 2006, p. 237)

Este trajeto exige um duplo distanciamento, conforme se lê no livro seguinte:

eu tinha um anjo, que havia preso a uma imagem piedosa, que me oferecera meu pai - nos anos da minha infância. $\mathrm{O}$ anjo conduzia-me ao lado do abismo, mas ambos estávamos presos ao seu recto declive, ele porque me guiava, eu porque era um humano.

Então, para eu vir para junto de vós ser cantor de leitura e precursor da sensualética nesta Casa, o anjo desprendeu-me da imagem piedosa, e desprendeu-se igualmente dela para tornar-se um trajecto de figura (LLANSOL, 2007, p. 161)

Para Llansol, "a presença angélica é de beleza, de louvor e de temor", embora outros

só dela captem a vertente do temor. Fogem, reflexo condicionado da identidade, quando seria possível, creio, trabalhar o reflexo: em vez de fugir do temor, acolher o louvor e a beleza. Apoiar-se na força do anjo, como vejo fazer no judo, no surf, e em alguns dos ditos desportos radicais. (LLANSOL, 1996, p. 83)

Sem nada entender de "angeologia", procura captar o movimento da presença angélica que de diferentes modos se manifesta: "mudam todos os dias os querubins que aparecem dançando a cena do texto; o seu canto de louvor é sempre de louvor, de temor e de beleza, mas nunca é igual" (LLANSOL, 1996, p. 78). “Todo o Anjo é terrível”, afirma Rilke em sua primeira elegia de Duíno (RILKE, 1972, p. 3), poeta cujos poemas em francês a autora traduzia na mesma época em que escrevia Inquérito às quatro confidências, dedicado a Vergílio Ferreira, um "torvelinho de luz" (LLANSOL, 1996, p. 183). Llansol não foge à terribilidade do anjo. Ao confrontar-se com o outro/a alteridade, trabalha o reflexo do temor de arriscar a identidade e alcança a vertente do louvor e da beleza. Aprende com Rilke e segue adiante: "o encontro entre mim e Rilke é tão estranho: o seu anjo não vem a caminho; amo-o profundamente, e digo-lhe adeus, adeus" (LLANSOL, 1996a, p. 11). 
Rilke, Vergílio e outros autores que ama profundamente "formam um labirinto no seu texto. São um só, potência magnífica que o jardim do pensamento permite". São diferentes cantos de um "único Autor Desconhecido", de uma "obra que, todos, continuamos a escrever", "um vergel ou um jardim, cultivando o fruto do conhecer": "Algo de semelhante à morada dos anjos em transformação , até o invisível ser posto em causa (demanda que o Vergílio fez sua, e teve tanta dificuldade em reconhecer)". No seu canto, diferentemente de Rilke e Vergílio, Gabriela procurou um modo de "dar à invisibilidade a grafia do visível" (LLANSOL, 1996a, p. 8-9), de "desfazer os nós da intensidade e de reconhecer o incognoscível. Não o invisível, como Rilke lhe chamava atravessando o seu pomar,/ nem o espaço do invisível, de que o Vergílio falou durante tanto tempo" (LLANSOL, 1996, p. 80-81).

\section{3.}

Muitos são os anjos mensageiros do Augusto em Amigo e Amiga. "A mulher de um só corpo separada" (LLANSOL, 2006, p. 96) soletra/grafa a primeira letra do alfabeto, inicial do nome do homem amado: "onde a letra tornou inteiro o nome, o nome ficou salvo" (LLANSOL, 1990, p. 102). A - "letra vagabunda", de "A. Nómada" (LLANSOL, 2006, p. 27, 22). A letra dobrada, como no princípio de Amigo e Amiga. A - de "ambo", nó de afeto que une Amigo e Amiga em um só corpo, como o laço que liga Ana e Myriam na sua estátua. A - de anjo, presença que atravessa o livro e "por toda a parte se insinua" (LLANSOL, 2006, p. 42, 245).

No "curso de silêncio" - o trabalho sobre (no sentido de sobreimpressão) o luto pelo Augusto -, a escrevente evoca vários anjos: o de Rilke, o da imagem da infância, o de Walter Benjamin e também o seu anjo, com quem, como vimos, mantém conversações, fazendo-o transitar de figurante a figura: "o Anjo de Rilke a [a mulher "cortada cerce"] acompanha. Idem, o de Benjamin. O meu, certamente, também não falhará” (LLANSOL, 2006, p. 107, 190).

A leitura de Rilke é "luz afirmativa à [sua] cabeceira", anjo textual que lhe permite abrir passagem à penetração do invisível, notadamente a Oitava Elegia (leitura implícita, embora não referida), sobre o olhar das criaturas, com todos os olhos, para o Aberto, e a Nona Elegia, de que recorda o verso "é entre martelos que o nosso coração sobrevive", transmutando-o em algo menos "implacável” do que o "definido" por Rilke, o que pede o abandono "da peculiar forma de olhar,/ olhos nos olhos/ unicamente", e a espera de "que o bulício da comunicabilidade das palavras, na sua efêmera passagem se rompa" (LLANSOL, 2006, p. 40, 59, 55-56). Através de uma sutil operação - "o ouvido da árvore que há muito [...] trouxera para a alma da criança" -, protegida e liberta pela "rama bravia dos céus de Parasceve" (o plátano), a Amiga joga o "jogo da liberdade do ouvido - "se eu não ouvir o oxigênio da folhas,/ a música é cega para mim” - e ouvê o 
"violento sopro musical do nascimento" de um "textualino - a qualidade cristalina que guarda o espaço entre as folhas" (LLANSOL, 2006, p. 58-60, 206, 53). Lembra-se então de que a criança lhe estava a mostrar "os contornos da terra apetecível à sensibilidade do anjo", "delineamentos postos à disposição do ruah" (LLANSOL, 2006, p. 59, 244), em consonância com o espaço edênico.

A evocação de Rilke, "qualquer coisa como 'um anjo à minha mesa", prepara a Amiga para a percepção da presença do Amigo, "sentado à mesa, no lugar que sempre ocupou”. E então, juntos, aproximam "os lábios para cantar a leitura - depois de ela ter cantado a escrita - a ouvir ler" (LLANSOL, 2006, p. 40, 135).

$\mathrm{Na}$ adenda, como previra, o seu anjo (não o exterminador) não falha: "O anjo está presente. Nem fala, nem ri, nem chora. Por toda a parte se insinua ${ }^{2}$. Esta sutil presença do anjo (grafado com minúscula, como "estere - medida de volume para madeira ou lenha", outro nome da mulher cortada cerce de seu ambo) é uma figuração do movimento amante, uma manifestação do silente, voz do que não tem voz humana, como a murmuragem dos "nervuredos" de Parasceve (LLANSOL, 2006, p. 245, 128, 206).

O ambo/anjo por todo o texto se insinua, como "um amor crescendo": "na beleza que é oferecida [à Amiga] através da atenção e paz que lhe [ao Amigo] dedic[a]" (LLANSOL, 2006, p. 15, 85); nas "criações feitas à boca das origens, a que Nómada chamava as massas de início"; no "rito de ressuscitação para os [seus] textos" (LLANSOL, 2006, p. 130, 243); na passagem, com Spinoza, da tristeza à alegria e desta ao júbilo. Prossegue o ambo "na emergência da ressuscitação para a eternidade". "Este é o jardim que a ausência permite" (LLANSOL, 2006, p. 78, 177).

Augusto retorna em Os cantores de leitura na figura de Tual, o cantor "que ousou pôr em causa o velho testamento de leitura". Também Rilke retorna através de seu poema sobre anjos cantores, lido pela voz de "Ciro - o sibilino?" (nome figural de Gabriela, que traduziu este e outros poemas de Rilke) (LLANSOL, 2007, p. 18), "cantor de leitura que [o] transdisse de uma língua a outra":

Meu coração, esta noite, fez dos anjos, cantores que se recordam...

Uma voz, quase integralmente sobreposta à minha, atraída por este excesso de silêncio,

eleva-se e decide

nunca mais voltar à minha;

dulcíssima e intrépida,

com quem ela vai se encontrar? (LLANSOL, 2006, p. 38)

"O que o texto tece advirá ao homem como destino" (LLANSOL, 2003 , p. 210). As figuras que voltam em encontros inesperados do diverso, afirmando o retorno do mútuo (não do mesmo), tecem com fios de luz o novo ser que virá. Este novo ser, anunciado de diversas maneiras, nomea- 
damente na cena cosmogônica (Lição XVII) de A restante vida (LLANSOL, 1982, p. 88), remete à criança vislumbrada por Spinoza, Nietzsche e muitos outros poetas e pensadores. A "criança sem rosto", sem nome e sem susto faz lembrar, segundo Augusto Joaquim,

a visão que teve Mestre Eckhart da criança que virá libertar Deus da sua solidão infeliz. "É por causa dessa visão e de algumas outras mais, como a de Ibn’Arabi, que sei que Isso que dá pelo nome de homem ainda não é mas, certamente, será (LLANSOL, 1987, p. 118)

$\mathrm{Na}$ "casa da leitura em flor" (LLANSOL, 2007, p. 18) o canto de leitura se eleva e prossegue. Prepara-se a vinda do texto-criança, anunciada em diversos livros, como a da criança-asa de Parasceve: "Eu te saúdo, Alguém-texto" (LLANSOL, 2001, p. 175):

Se uma força descritiva chegar a transformar-se numa criança rara,

será o texto. Texto-querubim, nunca imaginei que pudesse ler-se em voz alta. Mas é preciso cuidar a leitura, porque a $\mathrm{voz}$ - se for incerta no seu deserto - mata, mata a leitura e o texto o tom da voz a não impostura das suas pausas de silêncio

é determinante para o cuidado fraterno a ter com as figuras, que estão por detrás de nós,

no seu desejo de abrir para si o Ler.

Ler é, então, semelhante a um vagido, e a criança, se for um verdadeiro texto-anjo

cresce (LLANSOL, 2007, p. 38)

\section{4.}

Gabriela tem "o mesmo tropismo pela luz" (LLANSOL, 1996a, p. 9) que o poeta das Elegias de Duíno. Mas outra é a luz da estética do fulgor, outros os anjos em movimento na ordem figural, pois "o movimento é o sol dos equilibristas" (LLANSOL, 2006, p. 238) e um Anjo a caminho é uma boa definição de figura.

No seu declarado fascínio pela luz é possível apontar um atributo luciferino, na acepção de Lúcifer ${ }^{3}$ na mitologia romana (latim lux fero, portador da luz, a estrela da manhã, como aprece referido por Ovídio). Em certo sentido, na assunção positiva da rebeldia (Geografia de rebeldes é justamente o título da primeira Trilogia), o texto llansoliano guarda afinidade com Lúcifer, na tradição cristã identificado com o Anjo Rebelde (anjo da ordem dos querubins, caído ou decaído do céu, por cobiçar um poder maior), porém libertando-o da satanização de que foi alvo ao longo dos séculos, nomeadamente a partir dos séculos XVI e XVII, quando ocorreu “a primeira 'explosão diabólica”' (DELUMEAU, 1990, p. 239). A postura rebelde tem implicações com o projeto do humano ileso, pleno: "seremos 
incólumes se não separarmos o corpo e a alma". A sua "forma de rebeldia foi tão-só a recusa de o [o seu corpo] viver mutilado" (LLANSOL, 1985, p. $145,141)$. Não por soberba, por desejo de onipotência divina, mas como enfrentamento do medo do que nos foi "inculcado", "de tal modo os nossos preconceitos são os pensamentos dos outros", conforme reflete Copérnico, assumindo "o risco de observar e de pensar por [si] mesmo": "Que eu não queria ser Deus;/ eu queria somente conhecer o fenômeno raro" (LLANSOL, 1986, p. 173, 175). Do seu enfrentamento do medo resultaria o livro Das revoluções das orbes celestes ${ }^{4}$, que mudaria o paradigma científico. $\mathrm{Da}$ relação amorosa triádica, fora da luz comum - o encontro inesperado entre Copérnico, Isabôl (Isabel de Portugal) e Hadewijch (beguina flamenga, autora de poemas de erotismo místico) -, vislumbra-se a possibilidade de transmutação dos afetos, a "esperança de que o Hermafrodita não fosse a figura final do humano: a esperança que guarda os sexos em número ímpar, e os mantém abertos ao conhecimento do amor" (LLANSOL, 1986, p. 11).

Podemos considerar ainda no projeto de Llansol a presença de uma força demoníaca (no sentido empregado por Antoine Compagnon, ao desembaraçar a teoria literária da "linguagem corrente sobre literatura”, 1999, p. 17), que a impele a "deslocar o centro nevrálgico do romance, descentrá-lo do humano consumidor de social e de poder, operar uma mutação da narratividade e fazê-la deslizar para a textualidade”. Esta força ou "energia criadora" leva-a a travar um incessante combate contra a mediocridade do senso comum, a previsibilidade das formas estereotipadas e dos lugares comuns, enfim, a manter uma vigilância constante contra a impostura da língua, procurando modos de "romper [os] cenários de 'já visto' e 'revisto"' e de despertar no leitor "sedento de novo" (LLANSOL, 1994, p. 120, 118) a apetência de mais-belo.

Em outro registro de seus cadernos, Gabriela invoca "os espíritos tutelares da casa” para que a acompanhem no trabalho na Quinta de Jacob (que, na época, ainda não se revelara inteiramente frustrante, embora já evidenciasse tensões e dissonâncias) (LLANSOL, 2009, p. 210). Os espíritos tutelares podem ser associados aos anjos protetores e também aos deuses Lares, divindades domésticas dos romanos, incumbidas da proteção da morada e da família, cujo nome liga-se ao lugar da casa onde se acende o fogo, a lareira, palavra derivada do latim "lar". Mas é bem possível que Gabriela se refira às figuras, por vezes designando-as de "espíritos": "um espírito feminino quer entrar, um espírito de perseverança e mansuetude. É um espírito sorridente, soube coser como quem sorri" (LLANSOL, 2009, p. 220). Este trecho, com ligeiras alterações, participará da composição da figura de Infausta, heterônimo feminino de Pessoa/Aossê: "Uma figura feminina quer entrar,/ Infausta,/ um espírito de perseverança e mansuetude. Modo sorridente, soube coser como quem sorri" (LLANSOL, 1985, p. 118).

Muitas figuras, nomeadamente as beguinas, assumem a função de guias: Margarida, em Na casa de Julho e Agosto, educa Luís M. "com venenos e contravenenos", para que se torne "o mais belo rio humano", "fon- 
te gotejante de linguagem" (LLANSOL, 1984, 105-6); Úrsula, em Causa amante, liberta Sebastião da "sua fatalidade de rei", dando-lhe "um lugar no seu jardim" - o jardim que o pensamento permite -, onde se torna "dom arbusto", e, em Inquérito às quatro confidências, liberta o Mais jovem "da sua mente hesitante", apontando-lhe "o seu destino de nascente no meio da floresta in-combustível” (LLANSOL, 1996, p. 180).

Gabriela refere-se em várias passagens ao ouvido visualizante, à capacidade de ouver, ou, recorrendo a um termo llansoliano, à sobreimpressão de planos sensoriais, que se mantêm não hierarquizados e distintos neste processo. Trata-se de uma técnica de escrita, de um modo de captar a imagem que nada tem de sobrenatural:

a escrita é tão só uma visão que é técnica de linguagem. Pessoalmente nunca escrevi uma palavra; nem vejo em palavras; ouço imagens que se confrontam a admirações de pensamento e que não serão nada se não nascerem com o corpo que lhes convém. (LLANSOL, 2011, p. 25)

As imagens "são caminhos [...] que nos fazem ter corpo" (LLANSOL, 2000, p. 35). Escrever é ouver imagens e dar-lhes o corpo que thes convém. Assim, "o encontro do Anjo com o seu Eros" - a escrita-transformação de "O lugar" de Herberto Helder -

começou por ser uma voz rouca por detrás do biombo. Era ao fim da tarde numa Lisboa de 1964, pluviosa, cinzenta. No quarto, cai a sombra. Por detrás do biombo a voz ilumina, aos poucos, a imagem campestre que traz desenhada no pano, em outro lugar de que, então, ignorava o nome: o ponto voraz, "o fim espelhado da terra", como dizia o poema (LLANSOL, 1996, p. 17)

Quando Gabriela iniciava a escrita, daïmons sonoros (no sentido grego) espalhavam-se pela casa. Segundo Augusto Joaquim ${ }^{5}$, eram perceptíveis "diversos sinais",

sobretudo um murmúrio audível. Os gregos acreditavam que haviam daïmons silentes e sonoros. $\mathrm{O}$ da filosofia, por exemplo, é silente e, normalmente, ler, em voz alta, um texto filosófico, dá vontade de dormitar, porque a atenção se dispersa, sem se elevar. Todos os daïmons possuem a sua elegância própria, mas só os sonoros têm o condão de elevar para a beleza. (JOAQUIM, 1996, p. 170)

A manifestação dos daïmons sonoros sugere o tilintar de berlindes (bolas-de-gude) em movimento, uma "corrida luminosa de cores/ Transparentes" que se ouve pela casa, quando se transformam "os brasões e lugares comuns" que rodeiam as crianças (LLANSOL, 2003, estância 114). Por essa razão, na "maior experiência de dor" - a perda do Augusto -, ao escutar o som da chuva, Maria Gabriela fica grata por encontrar um sinal sonoro do esposo ausente e a ele se dirige, principiando a "brincar com as 
palavras móveis": “ sentou-se a chuva à minha janela (a chuva, igual a berlindes que afirmavas que soavam quando eu atravessava o corredor)" (LLANSOL, 2006, p. 35, 37).

$\mathrm{Na}$ antiga Grécia, a forma de atuação dos daïmons, como uma "força que impulsiona o homem, levando-o para a ação", "aponta para um princípio ético que desempenha papel fundamental na formação do homem grego". A dimensão ética, visível no exemplo de Sócrates, que assumiu falar em nome do seu daïmon pessoal, propiciará a tipificação dos daïmons "em termos tanto positivos quanto negativos tendo em vista a diferenciação da fortuna entre a espécie humana". Assim, "ser agraciado" com um eudaímon "irá determinar uma existência harmônica". Mas o indivíduo também pode ter como guardião "um dysdaímon, um kakodaímon que lhe legará uma vida de dificuldades".

Para a ideia do Diabo, essa potencialização de daímones foi importante, sobretudo devido à sua presença muito mais próxima no cotidiano das pessoas que os deuses. Quando do início do cristianismo, a nova religião encontrou, no universo de expressão grega, um mundo de demônios que ainda não haviam sido "demonizados". Mas Paulo, a ponta-de-lança doutrinária do cristianismo, tratou de impiedosamente fazê-lo. Dessa maneira, o movimento de demonização de divindades rivais atingiu os intermediários do éter, abrindo caminho para a imagem moderna do demônio como uma das faces do Diabo. (PRADO, 2007, p. 72-3)

Os daïmons de Maria Gabriela, em consonância com o sentido original, são figuras de potência que impulsionam e acompanham a sua escrita. "A ética é o meio ambiente da beleza", afirma Llansol (LLANSOl, 2007 , p. 164). A atuação dos daïmons no texto llansoliano, dotado, por grande graça de textualidade, com o condão de elevar ao máximo para a beleza, pode ser definida como uma sensualética.

5.

Num trecho de Contos do mal errante, em vez de nomear o diabo, Gabriela recorre a um dos significados do termo (latim diabulum: aquele que divide, que separa): "enquanto ele, o divisor, divide, eu acumulo a amplitude do que é diversificável"; "só o Espírito pode voltar a unir o que o divisor separou" (LLANSOL, 1986, p 188, 194). As poucas referências ao demônio $^{6}$ (na acepção moderna do termo, construída ao longo do processo de demonização das divindades pagãs pelo cristianismo) surgem, por exemplo, em O Senhor de Herbais, quando a autora escreve sobre Jorge de Sena e suas Novas Andanças do Demônio (1966) ou sobre as perseguições inquisitoriais às mulheres acusadas de escrever textos inspirados pelo demónio" e sentenciadas à fogueira, como Jeanne de Louvière. Se Gabriela tivesse vivido na época da "caça às bruxas", certamente teria tido o mesmo 
destino, como ela sugere com ironia, ao pôr em paralelo o "digest" sobre a sua obra, redigido por um jornalista francês que a lera por alto, com o texto da condenação de Jeanne, redigido "no século XVII, não muito longe de Herbais" (LLANSOL, 2003, p. 320), pelo tribunal que a condenou. Felizmente, "nenhum dos '[s]eus' ali passara, excepto incógnito, nem Hadewijch ali estivera. Se ali houvesse vivido, ou seja, abertamente lida, teria sido queimada como bruxa herética" (LLANSOL, 2003, p. 28).

Conforme o subtítulo deste livro indica, "Breves ensaios sobre a reprodução estética do mundo e suas tentações”, Gabriela apropria-se ironicamente da linguagem do mundo do poder e/ou que de algum modo fundamenta a(s) estética(s) que pretende deslocar ("Senhor de Herbais", "tentação", "pecado", "bíblica 'redução a pó", "Crime e castigo"), como se depreende da conversa epistolar travada com Eusébia, que se tornou " $n a$ turalmente seu interlocutor realista" (LLANSOL, 2003, p. 14-31):

Se me perguntar, um dia, por que desejei esse lugar, responder-lhe-ei, na linguagem que entende: Herbais só sabia ensinar por tentação. Havia um profundo, profuso e inextinguível pecado no seu habitat. Compreende-me? Atraiu-me a excepcional qualidade do seu bom senso. Os seus proprietários haviam agido com uma maestria tal como representantes emblemáticos do senso comum que a mola do mundo era visível à vista desarmada. [...] Só depois enfrentei a casa, desafiando-lhe conscientemente a tentação. (LLANSOL, 2003, pp. 24-25)

Neste provocador livro sobre o pandemônio das estéticas, Gabriela "procura desdobrar algumas das extensões do realismo" (LLANSOL, 2003, p. 120). Se a sua escrita avançasse por desenvolvimentos temáticos ou por enredo, a história dos antigos proprietários da casa de Herbais daria margem a um livro do gênero "ascensão e queda dos Buddenbrook", típico da estética que se reproduz "há praticamente dois séculos", impondo-nos “a imagem de um só mundo, o do poder" (LLANSOL, 2003, p. 13, 47). Ou ainda, na extensão neo-realista, à "história amaldiçoada dos Simples", a humilhação dos "boné-na-mão" pelo Senhor: "Ah, Eusébia, esta não é a história que o meu texto lhe contaria. Pode crer que não. Esta é a história da casa de que me fala nas suas cartas" (LLANSOL, 2003, p. 26, 18).

O termo "tentações" do subtítulo, além de aludir ao mito bíblico da Queda - a tentativa de "uma via de conhecimento arriscada, autónoma” (LLANSOL, 2003, p. 62) -, suscita a interlocução com as demoníacas tentativas de Jorge de Sena, um "dos poucos autores que no século passado tentaram ultrapassar as 'tentações e os impasses' com que, em todo o Ocidente novelístico e romancista, se deparou o realismo". Sena "sabia que a Literatura era universal e tinha uma história de impasses acumulados e de alguns saltos resolvidos". Autor “multímodo, imaginativo, hábil”, tentou 
todas "as formas estéticas realistas", "um festival de fogo e de cinza", para deixar-se aprisionar pelo redil do "contacto emotivo", da "filofilia" (LLANSOL, 2003, p. 130-37).

"A minha participação na luz é uma pergunta" (LLANSOL, 1996, p. 22). O texto de Sena fascina porque é um texto que "pensa. A sua natureza é da pergunta que continua posta". Por isso o poeta de Metamorfoses (1963) integra a linhagem dos autores que "pertencem ao tronco de uma mesmo vibração, tem a mesma espiral luminosa interior [...], como uma coluna de fogo que se interroga e procura o seu anel" (LLANSOL, 1995, p. 3). Ao responder textualmente à pergunta de Sena, Gabriela vê-o como uma coluna de fogo anelante, nele percebendo também a insanável ferida que o liga a Camões:

Lembrava-me de Jorge de Sena que é Jorge Anés, no livro. Continuei pensando que o vira como ele desejara ter vivido. Havia nele uma bala, ou estilhaço, provinda de outros combates (quem sabe se da Campanha do Norte de África - Ceuta, 1549) que nunca ninguém conseguira extrair-lhe (LLANSOL, 1985, p. 128).

É possível perceber nestes outros combates uma alusão à seniana "dor de haver nascido em Portugal,/ sem mais remédio que trazê-lo n'alma" (SENA, 1988, p. 117) e ao destempero camoniano por "cantar a gente surda e endurecida" (Lus., X, 145). Melhor, porém, será associá-los à espiral luminosa de combates por uma língua nova.

Gabriela recolhe e transfigura diversos sinais de fogo ${ }^{7}$ do "armazém de sinais" ou "signografia" seniana (LLANSOL, 1996, p. 140-1), escrevendo-os à luz dos "encontros de confrontação" (LLANSOL, 1985, p. 105), no eterno retorno do mútuo. Em Causa amante, por exemplo, no capítulo "E ou 'Era impossível que o fogo ardesse", Jorge Anés, "sem lume que o aqueça - só que o queime", senta-se "no mesmo banco" que Comuns (nome figural de Camões). Postos a conviver no jardim que o pensamento permite, os dois poetas perdem-se "mutuamente no ritmo e no sentido das palavras". Quando "só uma voz percute", perguntando "o que era a língua?” (a tentação desse jardim?), um responde ao outro: "era impossível que o fogo ardesse". Jorge Anés senta-se também ao lado da narradora, na pedra que ela escolhera para esse encontro (alusão à pedra filosofal ${ }^{8}$ ?). "Durante uma visita", fala-lhe dos textos que escrevera - "tinha escrito sobre a matéria que se inflama que, quando se apaga, gasta o fogo" - e da procura da língua, dizendo-lhe "que o caminho era longo, mas que tivesse esperança,/ pois maior do que nós/ era a língua/ que nos esperava” (LLANSOL, 1984, p. 98-102).

Da combatente beleza também faz parte, é evidente, Fernando Pessoa, o falcão Aossê, cujos voos atravessam vários livros de Llansol. Talvez por essa razão, a autora decide renomear Jorge de Sena, invertendo-lhe a ordem das letras do sobrenome, tal como procede com o nome de Pessoa - "Pessoa, lido da direita para a esquerda, dava AOSSEP" (LLANSOL, 1985, p. 94), mas conservando-lhe o nome - Jorge Anés, no livro -, como 
faz com o de Luís de Camões, interlocutor privilegiado de Sena, a quem ele se dirigiu como um de "seus contemporâneos" (SENA, 1984, p. 95), re-nascendo textualmente com seu gêmeo figural: "Nascimento de Jorge Anés e de Luís Comuns, a partir das pombas que revoam a Praça Luís de Camões" (LLANSOL, 1985, p. 8). Do por demais conhecido ao desconhecido nascente, Gabriela experimenta a vertigem de ousar alto voo, entre poetas vivos que lhe interessam mais, como diria Ruy Belo.

É tentador associar Anés, figura partícipe da coluna de fogo que se interroga e procura o seu anel, a "anéis que a mão escriturante necessita portar, até para encetar as suas próprias metamorfoses escriturais” (SANTOS, 2001, p. 109), caminho de certa forma já apontado:

o anagrama ANÉS, ao alterar a tonicidade do nome original, não estará buscando foneticamente a associação com anéis? Anéis são elos, liames - aquilo que pode relacionar objectos ou pessoas. Mas anéis são também objectos de adorno - dedos que, com coreografia própria, produzem a escrita. Uma escrita talvez crivada de ligações, como aquelas que fazem ecoar Sena em Llansol. (SANTOS, 1994, p. 105)

No caso particular de Sena, a inversão remete de imediato ao demoníaco, marca inconfundível das suas andanças, na poesia e na prosa, como referimos em estudos anteriores. Numa das "fórmulas de evocação" do poema "homenagem a Sinistrari (1602-1701) autor do 'Demonialitate", Sena recorre em "verso e meio" à escrita "às avessas": "melav oan em sonamuh ueq/ mim on edniv!” (SENA, 1989, p. 148).

Trazer Jorge de Sena para a ordem figural, metamorfoseá-lo, implica reconhecer-lhe a potência de escrita. Gabriela acolhe-o na casa do texto com a mesma serenidade (uma forma muito própria de lidar com a angústia da influência...) com que recebe a visita de Musil em Herbais, ou seja, sem recear as "vertigens da ressonância" e sem deixar de mostrar ao "hóspede" os "espaços” em que há "marcas suas" (LLANSOL, 1985, p. 63). Assim, numa das polêmicas notas do igualmente polêmico O Senhor de Herbais, depois de "referir o apreço que sempre cultiv[ou] por seu labor, e explicar porquê", não deixa de sublinhar em que aspecto fundamentalmente dele se distancia - o contacto emotivo com o seu país de origem, com "as 'nossas coisas": "Nunca lhe ocorreu que essa khora fosse sequer pensável em termos de identidade colectiva viável (e que, caso o fosse, talvez não merecesse o esforço...), e que ser português é, deveras, um facto mas não necessariamente um destino" (LLANSOL, 2003, p. 129, 138, 132).

De Peregrinatio ad loca infecta (1969) a Exorcismos (1962), numa linha expressiva que remontava ao poema "Exorcismo" de Coroa da terra, Sena construiu as bases de um discurso animado pela apóstrofe imprecativa, em que o diabólico simbolizava todos os males da pátria e da humanidade. (CARLOS, s.d., p. 133) 
Nas palavras de Maria Gabriela, "raramente se viu na literatura portuguesa um tal fogo de artifício a espirrar enxofre sobre a quermesse lusa" (LLANSOL, 2003, p. 137). Fogo e enxofre são conhecidos elementos infernais (Apocalipse 19: 20). Outro é o fogo que "chama" o texto llansoliano. É bem provável que a autora tenha lido as observações de Eduardo Lourenço sobre o "Diabo que desde o primeiro conto de Andanças, Sena nos apresentou, muito português e ortodoxamente, como impotente. As mil formas do demoníaco são as mil e uma formas da impotência humana transfiguradas em valor”. Se a esta arguta lição juntarmos o que a antecede e prepara - "a essência do demoníaco é a sua nomeação. Só a infância lhe escapa, a verdadeira e a que cada qual salvaguarda ou conquista [...]" (LOURENÇO, 1994, p. 179) -, teremos elementos para pensar por que Llansol prefere não nomear o Diabo ou ainda por que refere, com insistência e de modo singular, o anjo, a criança e a "Casa de Infância” (LLANSOL, 2001, p. 156) em sua obra. O intento do seu texto é encontrar formas de pujança que permitam escapar da impotência. Por isso prefere invocar figuras como a de Parasceve (grego paraskevè: entre os hebreus, a sexta-feira, dia dos preparativos para a celebração do sábado; na liturgia católica, a sexta-feira santa, véspera da aleluia): "Sei agora, ó texto, o que meu filho me dirá./ Chamarei por ele: 'Parasceve!',/ e ele dir-me-á: 'Sim, mãe”' (LLANSOL, 2001, p. 180).

Retomando a citada nota de O Senhor de Herbais sobre a sua relação com Sena, a autora conclui, procurando manter o distanciamento exigido pelo olhar crítico, em conformidade com a proposta dos "ensaios literários" anunciados no subtítulo do livro, e também para distinguir as andanças senianas do caminho escolhido para o seu próprio combate, mas, ao mesmo tempo, sem deixar de reconhecer a sua "dívida a Sena" e de lhe prestar uma respeitosa homenagem: "Apesar do muito que lhe devo, preferi escrever as 'novas andanças do fulgor"' (LLANSOL, 2003, p. 137-8). Como declarara a respeito de Rilke, ama-o profundamente, e diz-lhe adeus, adeus.

\section{6.}

Sabendo que "quem escolhe a palavra, decide o real", como tantas vezes lhe lembrava o Augusto (LLANSOL, 1987, p. 28), em lugar de escolher falar sobre o inferno, ou privilegiar o seu oposto, o paraíso, Llansol decide abrir acesso ao real do espaço edênico: "a maioria dos humanos está muitíssimo mais disposta a acreditar que o inferno existe, do que alguma vez aceitará o espaço edénico como possível, quanto mais real". "Espaço edênico" foi o termo "mais adequado" que encontrou para nomear o "lugar" recorrente em seus textos - ou melhor, a "forma de comunicação fulgurante e generalizada entre todos intervenientes ou figuras, sem nenhum privilégio dos humanos" -, embora, "ao chamá-lo assim, [s]e visse obrigada a desconstruir uma tradição religiosa”. O espaço edênico não está 
"na origem do universo", "sempre existiu e não só no princípio dos tempos". "Não é fixo, como sugere a tradição, mas elaborável segundo o desejo criador do homem" (LLANSOL, 1995, p. 1-2). Precisou desconstruir também uma tradição mítico-literária, de Cristo/Orfeu/Ulisses/Enéias a Une saison en enfer (1873) de Rimbaud: "Em Parasceve, não há descida aos infernos. Há ritmo, há espaço, há voz” (LLANSOL, 2001, p. 13). Neste novo Éden há metamorfose. Não há Queda. Não há morte: “Anna [Magdalena Bach] diz ao Anjo: - Provar continuadamente a maçã do conhecimento não é motivo de condenação. - o Anjo ouvia, e Anna falara sem revolta, com o espírito soberano - de que enuncia uma nova lei" (LLANSOL, 1994a, p. 91).

A concepção desse jardim implica outra posição "face a Deus", além da religiosa, da mística e da agnóstica - "uma nova prática libidinal de grupo", a que Llansol chama "gestalt criativa incorporada em mulheres, homens, animais, plantas e paisagem,/ que toma a seu cargo a realização da boa nova anunciada à natureza e aos humanos" (LLANSOL, 1987, p. 119). Nesse sentido, Llansol escreve um novo evangelho (grego: euangelion, eu, bom, -angeliun; mensagem, boa-nova) apócrifo.

Sem ser "crente" nem "descrente", encontra um modo mediato, via estética - e não através da filosofia ou da teologia - de aceitar o convite "a uma relação pessoal" com "Esse/Presença", cujo "nome próprio" não nomeia "(e que nos [s] eus textos escrev[e] em letras minúsculas, ou então Eus, embora não se trate, de modo algum, do mesmo género de presença)". Se "é muito difícil falar d'Ele, de Esse", é ainda "mais difícil falar sobre o Amor". Cabe à forma humana, "no Amor, ser os sentidos (a sensualidade e os sentimentos) da Presença não humana; no Amor, ser a consciência das formas-animais e vegetais, a consciência da paisagem", procurando manter-se "perto, em risco [pois o "ponto-voraz da fusão amorosa chama"], testemunhando diante da Presença o que o real é, e ela não sente, abrindo às outras formas a boa-nova da criação" (LLANSOL, 1994, p. 139-40, 144-46). O texto, anjo mensageiro, capta o movimento da presença amante, anuncia o ambo formado pelo encontro do dom poético com a liberdade de consciência.

Sobre as raras referências ao demoníaco, dois exemplos: o primeiro, associado à imutabilidade, princípio que se opõe ao da disponibilidade das figuras à metamorfose: "o mundo imutável é o universo demoníaco onde não há livre arbítrio" (LLANSOL, 1986, p. 186); o outro, ligado à referida "tentação" da estética realista, ainda vigente na atualidade: a escrita realista "adensa o mundo, não o desdobra, torna-o demoníaco e inabitável, hermeticamente fechado a qualquer esperança ponderada”. É sintomático, lembra Llansol, "que autores que se dizem cristãos insistam numa estética de cinza, quando outros, como é o [s] seu caso, abertamente não crentes, procuram caminhos para a ressuscitação (...) para o mundo do humano". "Ressuscitar", diz Eusébia a Llansol, é a "única esperança que me resta do 
cristianismo imbecil em que nasci” (LLANSOL, 2003, p. 47, 233). A autora acolhe o termo ressuscitar, destituindo-o do caráter religioso e dos estigmas da crucificação - a necessidade da passagem pela dor e pela morte.

Cristo ou Dionísio? "O salvífico em troca da perda definitiva de júbilo, ou este, em troca da dissolução da identidade, são alternativas fundadas numa troca não verdadeira”. Em busca da troca verdadeira, entre alternativas irredutíveis entre si, propõe uma terceira via, não excludente. Não rompe com Dionísio, como "Hölder[lin]", para "aceitar o/ nada da razão ou um corpo mortificado", mas por “o fulgor estar tão próximo do encanto do mundo, de que o segredo apenas Dionísio conhecia"; não rompe com "o Crucificado", como "Friedrich N.", "por o fulgor estar tão próximo da misericórdia, e esta ser a única palavra que a morte é realmente incapaz de corromper” (LLANSOL, 2000, p. 136, 230-33): “a misericórdia dará ao pó o fulgor que o fez nascer" (LLANSOL, 1999, p. 14). O texto do fulgor, ao reescrever, a bíblica redução a pó, conforme a tradução consagrada do versículo do Gênesis - "tu és pós e em pó e ao pó hás de retornar" (Gen 3: 17-19) -, devolve-nos, com esperança ponderada, a luminosidade que, na passagem de uma língua outra, nos foi roubada: "tu és poalha dourada, $e$ em poalha dourada te hás-de tornar” (LLANSOL, 1994, p. 115).

\section{7.}

"O fulgor é móvel” (LLANSOL, 1998, p. 107). Os anjos de Llansol "verbam o há" (LLANSOL, 1996, p. 134) em "MetaVelozMorfose" (LLANSOL, 2001, p. 152). São forças, formas de potência, "corre[m] com a mensagem" (LLANSOL, 1994a, p. 87), em luminosa e melodiosa corrida de cores transparentes, um torvelinho de intensidades a chamar-nos, ao contrário do Angelus Novus de Klee - o Anjo da História -, imobilizado e arrastado pela contínua catástrofe do progresso, contemplando impotente a acumulação de ruínas sobre ruínas (BENJAMIN, 1987, p. 226). São grafias do movimento amante, cintilações do "intenso breve" (LLANSOL, 1987, p. 32), fulguram e retornam, modificados a cada novo encontro. "O edénico não evanece,/ cresce" (LLANSOL, 2003, estância 148). Como o texto-querubim, como uma criança.

\section{REFERÊNCIAS BIBLIOGRÁFICAS}

BENJAMIN, Walter. Sobre o conceito da história. In: Magia e técnica. Arte e política. 3. ed. São Paulo: Brasiliense, 1987.

CARLOS, Luís Adriano. Rimbaud e Jorge de Sena: da vidência ao exorcismo. In: <ler.letras.up.pt/uploads/ficheiros/5570.pdf>. p. 127-141.

COMPAGNON, Antoine. O demônio da teoria: Literatura e senso comum. Belo Horizonte: UFMG, 1999. 
DELUMEAU, Jean. História do medo no Ocidente. São Paulo: Companhia das Letras, 1990.

JOAQUIM, Augusto. Durante anos (Posfácio à 2. ed.). In: LLANSOL, Maria Gabriela. Causa amante. Lisboa, Relógio d’Água, 1996. pp. 165-211.

LINK, Luther. O diabo. A máscara sem rosto. São Paulo: Companhia das Letras, 2000.

LLANSOL, Maria Gabriela. Amigo e Amiga. O curso de silêncio de 2004. Lisboa: Assírio \& Alvim, 2006.

.Um beijo dado mais tarde. Lisboa: Rolim, 1990.

_. Os cantores de leitura. Lisboa: Assírio \& Alvim, 2007.

_.Causa amante. Lisboa: A Regra do Jogo, 1984.

_. Um falcão no punho. Diário I. Lisboa: Rolim, 1985.

_. Finita. Diário II. Lisboa: Rolim, 1987.

_. Inquérito às quatro confidências. Diário III. Lisboa: Relógio d’ Água, 1996. tos. Lisboa: Relógio d’ Água, 1996a.

Introdução. In: RILKE, Rainer Maria. Frutos e apontamenUm jardim entre oliveiras (Prefácio). In: DE LISIEUX, Thérèse Martin. O alto voo da cotovia, Thérèse Martin. Trad. e pref. de M. Gabriela Llansol. Lisboa: Relógio d’Água, 1999. pp. 7-16.

Rolim, 1994.

Lisboaleipzig 1. O encontro inesperado do diverso. Lisboa:

. Lisboaleipzig 2. O ensaio de música. Lisboa: Rolim, 1994a.

A literatura, muitas vezes. In: Caderno de Leituras. Lisboa: Mariposa Azual, 2011. p. 25.

. Livro de Horas I. Uma data em cada mão. Lisboa: Assírio \& Alvim, 2009.

Porto, 1995. p.1-4.

No Espaço Llansol. In: Público - Caderno Leituras. n. 1786.

. Onde vais, drama-poesia? Lisboa: Relógio d’Água, 2000.

. Parasceve. Puzzles e ironias. Lisboa: Relógio d’Água, 2001.

. Os pregos na erva. Lisboa: Rolim, 1987a. 
LOURENÇO, Eduardo. Jorge de Sena e o demoníaco. In: Ocanto do signo. Lisboa: Editorial Presença, 1994. p. 172-179.

PRADO, Márcio Roberto do. Vésper. Exercício de Filosofia da Literatura. UNESP: Araraquara, 2007 (Tese de Doutorado).

RILKE, Rainer Maria. Elegias de Duíno. Trad. Dora Ferreira da Silva. Porto Alegre: Globo, 1972.

SANTOS, Cristina Maria Paes dos. Ao encontro de uma língua frátria - pelo caminho escrevível de Maria Gabriela Llansol. Rio de Janeiro: UFRJ, Faculdade de Letras, 2001 (Tese de Doutorado).

SANTOS, Gilda da Conceição. Sena e(m) Llansol: tramas que o feminino cria (digressões no limiar de um fascínio). In: Terceira margem. Revista da Pós-Graduação em Letras da UFRJ, 1994. pp. 102-106.

SENA, Jorge de. Trinta anos de poesia. Lisboa: Edições 70, 1984. . Poesia I. Lisboa: Edições 70, 1988.

(Recebido para publicação em 31/10/2011, Aprovado em 27/11/2011)

\section{NOTAS}

1 Tendo em vista os limites deste estudo, abordarei apenas alguns exemplos de presenças angélicas no texto de Llansol. A amplitude e a complexidade do tema exige posterior desenvolvimento.

$2 \mathrm{O}$ anjo que por toda a parte se insinua pode se revelar em qualquer figura ou lugar, inclusive através de um "rapazinho atrasado mental, chamado Gabriel" (LLANSOL, 2006, p. 245).

3 A primeira identificação de Lúcifer, a estrela da manhã (planeta Vênus), com Satã, o anjo caído, teria vindo de Isaías: "Como caíste do céu, /ó estrela d’alva, filho da aurora" (Is 14, 12), embora, segundo o pesquisador Luther Link (2000), que analisou a iconografia do Diabo do século VI ao XVI, Isaías não estivesse se referindo a uma entidade, mas valendo-se de uma metáfora referente aos excessos de um rei tirânico da Babilônia, que caiu no mundo dos mortos. Posteriormente, este rei babilônico foi identificado com o Diabo.

4 Copérnico, “cónego (...) prudentíssimo", manteve seus “cálculos impublicados” (LLANSOL, 1985, p. 105) até perto de sua morte, divulgando a sua teoria apenas entre astrônomos (manuscrito Pequenos comentários de Nicolau Copérnico, 1530). Somente em 1540 permitiu que seu discípulo G. J. Rhaticus publicasse as suas ideias (Narrativa acerca das obras de Copérnico sobre revoluções). Salvou-se, assim, de ter o destino de Giordano Bruno, que vinte anos mais tarde acrescentou à teoria heliocêntrica a ideia do Universo infinito, tendo sido condenado à fogueira pela Inquisição. 
5 Augusto Joaquim refere outro exemplo de manifestação do daïmon sonoro, quando Vergílio Ferreira se encontrava na Casa da Saudação, um estúdio anexo à casa de Llansol, em Colares: "Vejo o Vergílio, no meio das explicações, dirigir-se para a janela e sentar-se à mesa, defronte do jardim. Só disse que ali escreveria. Calámo-nos. Não havia qualquer objecto sobre a mesa. Não havia obviamente nem lápis, nem papel, mas o corpo do Vergílio colocou-se espontaneamente na postura de escrever, com o rosto ligeiramente lançado para o verde do jardim. Era a presença do daïmon sonoro grego. Foi breve, mas todos entendemos" (JOAQUIM, 1996, p. 171).

6 Emprego como sinônimos os termos “diabo" e "demônio", embora haja uma distinção. Com base em algumas passagens da Bíblia, por exemplo, é possível dizer que o diabo tem seus mensageiros, os demônios. Lucas chama os demônios de "espíritos malignos" (Lc 8: 2) e "espíritos imundos" (Lc 8: 29). Mateus chama Beelzebu de "príncipe dos demônios" (Mt 12: 24) e refere-se ao "diabo" e "seus anjos" (Mt 25: 41).

7 Sinais de fogo é o título de um romance de Jorge de Sena, publicado postumamente e inacabado em 1979.

8 Pedra filosofal é o nome de um livro de poemas de Jorge de Sena (1950).

9 A concepção de Deus na obra de Llansol é extremamente complexa e sua análise ultrapassa os limites deste estudo. 